\title{
Adölesan Futbolcuların Başarı Motivasyonu ile Algıladıkları Antrenör Davranışlarının İlişkisi
}

\author{
İhsan Sarı ${ }^{1}$ Erolcan Çelik ${ }^{2} \quad$ Muharrem Aydın $^{3} \quad$ Selçuk Köytepe ${ }^{4}$
}

\begin{abstract}
$\ddot{\mathbf{O} z}$
$\mathrm{Bu}$ çalışmanın amacı, antrenör davranışlarının adölesan futbolcuların spora özgü başarı motivasyonu ile ilişkisini belirlemektir. Bu amaçla bu araştırmaya, 12-18 yaş arasındaki 192 erkek futbolcu katılmıştır. Veri toplama aracı olarak, Kişisel Bilgi Formu, Antrenör Davranışlarını Değerlendirme Ölçeği ve Spora Özgü Başarı Motivasyonu Ölçeği kullanılmıştır. Veriler tanımlayıcı istatistikler, Pearson korelasyon analizi ve regresyon analizi ile değerlendirilmiştir. Güç gösterme güdüsü ile teknik becerilerin öğretimi, zihinsel hazırlık, hedef belirleme, yarışma stratejileri ve olumlu antrenör davranışları arasında pozitif ve anlamlı ilişkiler bulunmuştur. Başarıya yaklaşma güdüsü ile antrenman ve kondisyon, teknik becerilerin öğretimi, zihinsel hazırlık, hedef belirleme, yarışma stratejileri ve olumlu antrenör davranışları arasında pozitif ve anlamlı ilişki bulunmuştur. Başarısızlıktan kaçınma güdüsü ise teknik beceri ile negatif ve anlamlı; olumsuz antrenör davranışları ile pozitif ve anlamlı ilişki göstermiş̧ir. Regresyon analizi sonucuna göre antrenörün teknik beceri öğretimi ve zihinsel hazırlık davranışları sporcuların güç gösterme güdüsünü $\% 17$ oranında yordamıştır. Olumsuz antrenör davranışları ise başarısızlıktan kaçınma güdüsündeki varyansın \%10'unu açıklamıştır. Birçok olumlu antrenör davranışının, sporcuların başarıya yaklaşma ve güç gösterme güdüsü ile olumlu olarak ilişkili olduğu söylenebilir. Özellikle antrenörün teknik beceri öğretimi ve zihinsel hazırlık davranışları, sporcuların güç gösterme güdüsüne katkı sağlamaktadır. Öte yandan, olumsuz antrenör davranışlarının sporcuların başarısızlıktan kaçınma güdüsünü artırabileceği söylenebilir.
\end{abstract}

Anahtar Kelimeler: Antrenör davranışı, güdülenme, başarı motivasyonu, adölesan

\section{The Relationship between Adolescent Athletes' Achievement Motivation and Perceived Coaching Behaviours}

\begin{abstract}
The aim of this study was to determine the relationship between coaches' behaviors and adolescent football players' achievement motivation. 192 male football players between the ages of 12-18 participated in this study. Personal information form, Coaching Behavior Scale for Sport and Sports-Specific Achievement Motivation Scale were used as data collection tools. There were positive and significant relationships between

1 Sorumlu Yazar; Sakarya Uygulamalı Bilimler Üniversitesi, Sakarya-Türkiye, $\underline{\text { sariihsan@yahoo.com }}$ https://orcid.org/0000-0002-9090-8447

2 Sakarya Uygulamalı Bilimler Üniversitesi, Sakarya-Türkiye, erolcancelik3@gmail.com https://orcid.org/0000-00018099-0857

${ }^{3}$ Sakarya Uygulamalı Bilimler Üniversitesi, Sakarya-Türkiye. aydinmuharrem2021@gmail.com, https://orcid.org/00000003-4371-9982

${ }^{4}$ Sakarya Uygulamal1 Bilimler Üniversitesi, Sakarya-Türkiye. b171906001@ @ubu.edu.tr, https://orcid.org/0000-0002$\underline{0917-6403}$
\end{abstract}


motivation to achieve power and teaching of technical skills, mental preparation, goal setting, competition strategies and positive coaching behaviors. There was a positive and significant relationship between motivation to achieve success and training and conditioning, teaching technical skills, mental preparation, goal setting, competition strategies and positive coaching behaviors. Motivation to avoid failure was negatively and significantly correlated with technical skill whereas it positively and significantly correlated with negative coaching behaviors. According to regression analysis, technical skill teaching and mental preparation behaviors of coach predicted athletes' motivation to achieve power by $17 \%$. Negative coaching behaviors, on the other hand, explained $10 \%$ of variance in motivation to avoid failure. Coaching behaviors are positively related to motivation to achieve power and achieve success and show strength. In particular, coaches' technical skill teaching and mental preparation behaviors contribute to athletes' motivation to achieve power. It can be concluded that negative coach behaviors can increase athletes' motivation to avoid failure.

Keywords: Coach behavior, motivation, achievement motivation, adolescent

\section{GíRiş}

İnsanlar hayatları boyunca pek çok dönem yaşamaktadırlar. Adölesan dönem, bunlar arasında en kritik öneme sahip olanlardan biridir. Adölesan bireyler, bu süreç içerisinde çevrelerindeki yetişkinler ile etkileşim içindedir ve onlardan gelecek yardıma ihtiyaç duymaktadırlar (Şahin ve Özçelik, 2016). Yardıma ihtiyaç duymalarının en önemli nedenlerinden biri, adölesan bireylerin ruhsal dalgalanmalara neden olan hormonal değişimleri ilk kez bu kadar yoğun yaşamaları olduğu belirtilmiştir (Jensen, 2017). Hormonal değişimlere ek olarak vücudun davranışlardan sorumlu yapısı olan prefrontal korteks, bu dönem içinde hâlâ gelişim evresindedir ve bu durum hormonal değişimlerle de birleşince; istikrarsız, duygusal olarak ani iniş ve çıkışlara sahip ve oldukça dürtüsel bir davranış örüntüsü meydana gelebilmektedir (Jensen, 2017). Adölesan sporcuların içinde bulundukları bu önemli süreç boyunca onları spor yapmaya teşvik etmek, spordaki devamlılıklarını sağlamak ve onlara olumlu deneyimler sunmak büyük önem taşımaktadır. Bu önemli misyonun başlıca sorumluları da antrenörlerdir. $\mathrm{Bu}$ açıdan antrenörler sporcuların bu özel gelişimsel dönemini hesaba katarak onlarla ilişkilerinde kişisel bir yaklaşımı benimsemelidirler. Begel ve Burton'a (2017) göre ergenlik dönemindeki sporcu, bir sporu değil aynı zamanda bir kimliği de öğrenmektedir. Örneğin, sporcu paten kayan bir kişi olmak yerine bir patenci olabilmektedir. Ya da sertlik gerektiren branşlarla ilgilenen sporcuların sosyal yaşamlarında da sert davranışlarını sürdürme eğiliminde olmaları da bu konuya örnek olarak gösterilebilir. Yani sporcunun ilgilendiği branş bir aktivite olmaktan öte kimliğini inşa eden bir nitelik taş1yabilmektedir. Adölesanların spor deneyimleri yoluyla bir kimlik edinmeleri sebebiyle, onların spor deneyimlerini araştıran çalışmaların çok önemli olduğu söylenebilir.

Bununla birlikte, adölesan bireyleri spor ortamında tutan etkenler her sporcu için değişiklik gösterebilmektedir (Deelen vd., 2018). Kimi sporcu şampiyon olmak isterken kimi sporcu ise eğlence amaciyla spora katılabilir. Eğlence amaçlı katılım gösteren bireyler için ortamın cazibesi, sosyalleşme ve branşın keyif vermesi gibi unsurlar bireyi spor ortaminda kalmaya motive eden etkenlerken, şampiyonluk amaciyla yola çıkan sporcular, şampiyon olma hayali ile egzersize güdülenirler. Bireylerin spor yapmaya yönelmesi ve sporda devamlılık sağlamas1 onların spor motivasyonları ile ilgilidir. Sage'e (1977) göre motivasyon, bir kişinin çabalarının yönü ve yoğunluğudur. Sporcuların hedefleri doğrultusunda bazı durumları araması ve o durumlara yaklaşması çabanın yönünü tanımlarken, bu amaç doğrultusunda harcanan efor ise çabanın yoğunluğunu tanımlamaktadır. Ayrıca spor psikolojisinde motivasyon konusu oldukça geniş bir literatüre sahiptir ve çeşitli araştırmalara ek olarak birçok kuramsal temel de oluşturulmuştur.

Spora kat1lim gösteren bireylerin motivasyonları birçok etkenden etkilenebilmektedir. Örneğin erkekler, güç ve 
rekabet gibi içsel unsurlarla motive olurken; kadınlar kilo kontrolü ve görünüş gibi dışsal etmenlerle motive olabildikleri belirtilmiştir (Egli vd., 2011). Kültürel açıdan Amerikalı sporcuların Koreli sporculardan daha yüksek içsel motivasyona sahip oldukları belirtilmiştir (Kim vd., 2003). Bir başka çalışmada Çinliler ve Çin kökenli Amerikalılar karşılaştırılmış ve Çin kökenli Amerikalıların rekabet etme ve gelişim gösterme noktasında, Çinli sporcuların ise sağlık ve sosyal bağlılık noktasinda motive oldukları bulunmuştur (Yan ve McCullagh, 2004). Sporcuların motivasyonunu etkileyebilecek birçok unsur olmakla birlikte, bu unsurların en önemlilerinden biri antrenörlerdir. Sporcular ve antrenörler arasında yoğun bir etkileşim bulunmaktadır ve aralarındaki bu etkileşim performansın en önemli belirleyicisidir (Toros ve Duvan, 2011). Bunun da ötesinde iyi bir antrenörü ortalama antrenörlerden ayıran şeyin, teknik bilgi kapasitesinden daha çok insanları motive etme yeteneği olduğu da ifade edilmektedir (Weinberg ve Gould, 2015).

Antrenör davranışları ve sporcuların motivasyonları bağlamında yapılan çalışmalar incelendiğinde, antrenör sporcu ilişkisi ile sporcunun başarı motivasyonu arasında olumlu bir ilişkinin olduğu tespit edilmiştir (Mansoori ve Zardoshtiyan, 2016). Branş bazında futbolcu (Abakay, 2010), voleybolcu (Karimi vd., 2012), güreşçi (Khaksari vd., 2019) ve yüzücü (Karadağ, 2013) örneklemlerinde çeşitli araştırmalar gerçekleştirildiği görülmektedir. Yapılan çalışmalarda antrenör-sporcu iletişimi (Abakay, 2010; Karadağ, 2013) ve antrenörlerin liderlik davranışlarının (Karimi, 2012; Khaksari vd., 2019) sporcuların başarı motivasyonuyla ilişkisini ele alınmış ve genel olarak antrenör davranışları ile sporcuların başarı motivasyonları arasında anlamlı bir ilişki olduğu ortaya koyulmuştur. Her ne kadar ilgili alan yazında adölesan sporcular ile yapılan çalışmalar olsa da adölesan futbolcuların başarı motivasyonları ile algıladıkları antrenör davranışları ilişkisinin ele alınmadığ görülmektedir. Sporcular için uygun olan en ideal antrenör davranışı sporcuların özelliklerine göre değişiklik gösterebilir (Chelladurai ve Carron, 1983;
Chia vd., 2015). $\mathrm{Bu}$ nedenle, antrenör davranışlarının adölesan futbolcuların başarı motivasyonları ile nasıl bir ilişki içerisinde olduğunun araştırılması gerekmektedir.

\section{Araştırmanın Amact}

$\mathrm{Bu}$ araştırmanın amacı, antrenör davranışlarının adölesan futbolcuların spora özgü başarı motivasyonu ile ilişkisini belirlemektir.

\section{YÖNTEM}

\section{Araștırma Grubu}

$\mathrm{Bu}$ araştırma için Sakarya Uygulamalı Bilimler Üniversitesi Etik Kurulu'ndan 21.05.2021 tarih E.12090 sayılı etik kurul onay1 alınmıştır. Araştırmaya futbol branşından toplam 192 erkek sporcu $\left(\mathrm{X}_{\text {yaş }}=14.52 \pm 1.59 ; \quad \mathrm{X}_{\text {deneyim }}=5.68 \pm 2.02\right)$ katılmıştır. Sporcuların 6's1 millî sporcudur. Araştırmacıların en kolay şekilde ulaşabileceği sporculardan gönüllü olanların araştırmaya dâhil edilmesi kolayda örnekleme olarak isimlendirilmektedir (Coşkun ve diğ., 2017). Bu araştırmada kolayda örnekleme yöntemi kullanılmıştır.

\section{Veri Toplama Araçları}

\section{Sporcular İçin Antrenör Davranışlarını Değerlendirme Ölçeği (SADDÖ)}

Côté ve arkadaşları tarafından (1999) geliştirilen ve özgün adı "Coaching Behavior Scale for Sport (CBS-S)" olan ölçeğin Türkçe' ye uyarlaması Yapar ve İnce (2014) tarafından yapılmıştır. Ölçek, 1 (hiçbir zaman) ile 7 (her zaman) arasında 7'li Likert tipinde ölçüm yapmaktadır ve toplamda 7 alt boyut ve 47 maddeden oluşmaktadır. Ölçeğin altı alt boyutu olumlu (antrenman ve kondisyon, teknik beceri ögretimi, zihinsel hazırlık, hedef belirleme, yarışma stratejileri, olumlu antrenör davranışları), bir alt boyutu ise olumsuz (olumsuz antrenör davranıșları) değerlendirme yapmaktadır. Ölçeğin uyarlama çalışmasında alt boyutlara ait hesaplanan iç tutarlılık katsayısı değerleri; antrenman ve kondisyon $=0.86$, teknik beceri ögretimi $=0.85$, zihinsel hazırlık $=0.84$, hedef belirleme $=0.87, \quad$ yarışma $\quad$ stratejileri $=0.85$, 
olumlu antrenör davranıșları $=0.81$, olumsuz antrenör davranıșları $=0.79 \quad$ olarak hesaplanmıştır. Ölçeğin alt boyutlarının bu araştırma için hesaplanan Cronbach alpha $(\alpha)$ katsayısı değerleri ise Tablo1'de verilmiştir.

Aşağıda ölçeğin her alt boyutu için örnek maddelere yer verilmiştir.

Antrenman ve kondisyon: Kendimi güvende hissedeceğim bir antrenman programı sunar. Teknik beceri öğretimi: Çalışırken bana tavsiyelerde bulunur.

Zihinsel hazırlı: Baskı altında nasıl davranmam gerektiğine dair tavsiyelerde bulunur.

Hedef belirleme: Hedeflerime ulaşmak için stratejileri belirlememe yardim eder.

Yarışma stratejileri: Hazırlanma sürecinde daha iyi yapabilmem için odaklanmama yardim eder.

Olumlu antrenör davranışları: Bana birey olarak anlayış gösterir.

Olumsuz antrenör davranışları: Korkuyu bir antrenörlük metodu olarak kullanır.

\section{Spora Özgü Başart Motivasyonu Ölçeği (SÖBMÖ)}

Willis tarafindan (1982) geliştirilen ölçeğin Türkçe' ye uyarlaması Tiryaki ve Gödelek (1997) tarafından yapılmıştır. Ölçek toplamda üç alt boyuttan oluşmaktadır bunlar; güç gösterme güdüsü (12 madde), başarıya yaklaşma güdüsü (17 madde) ve başarısızlıktan kaçınma güdüsüdür (11 madde). Ölçek, 1 (hiçbir zaman) ile 5 (her zaman) arasında 5'li Likert tipinde ölçüm yapmaktadır. Ölçeğin alt boyutlarının bu araştırma için hesaplanan Cronbach alpha $(\alpha)$ katsayısı değerleri Tablo1'de verilmiştir.

Aşağıda ölçeğin her alt boyutu için örnek maddelere yer verilmiștir.

Güç gösterme güdüsü: Takım arkadaşlarım oyundaki mücadeleciliğime saygı duyar.

Başarıya yaklaşma güdüsü: Zor bir antrenman anında çalıştırıcının takdiri bana zorluğu unutturur.

Başarısızlıktan kaçınma güdüsü: Maçtan hemen önce gergin oluyorum ve olduğum yerde duramiyorum.

\section{Verilerin Analizi}

Verilerin analizinde SPSS 22.0 paket programı kullanılmıştır. İlk olarak verilerin dağılımlarının normal olup olmadığı değerlendirilmiştir. Basıklık ve çarpıklık değerlerinin -2 ve +2 arasında olması normal dağılım olarak değerlendirilmektedir (George ve Mallery, 2016). Ölçeklerin tüm alt boyutlarına ait basıklık çarpıklık değerlerinin 2 ve -2 aralığında olduğu yani normal dağıldığ1 görülmektedir. $\mathrm{Bu}$ nedenle parametrik testler uygulanmıştır. Değişkenleri betimlemek için tanımlayıcı istatistikler kullanılmıştır. Antrenör davranışları ile sporcuların başarı motivasyonu arasındaki ilişskiyi değerlendirmek için ise Pearson korelasyon analizi ve çoklu regresyon analizi (enter yöntemi) kullanılmıştır. Analizlerde anlamlılık düzeyi .05 olarak belirlenmiştir.

\section{BULGULAR}

Tablo 1 incelendiğinde sporcular için antrenör davranışlarını değerlendirme ölçeğinin antrenman ve kondisyon, teknik beceri öğretimi, zihinsel hazırlık, hedef belirleme, yarışma stratejileri ve olumlu davranışlar alt boyutlarına ait puanların 5.60 ile $\quad 6.40$ arasında olduğu; olumsuz antrenör davranışı puanının ise 2.98 olduğu görülmektedir. Spora özgü başarı motivasyonu ölçeğinin alt boyutları olan güç gösterme güdüsü 3.94 ve başarıya yaklaşma güdüsü 4.25 iken olumsuz alt boyut olan başarısızlıktan kaçınma güdüsü 2.97 olarak belirlenmiştir. 
Tablo 1. Sporcular İçin Antrenör Davranışlarını Değerlendirme Ölçeği ve Spora Özgü Başarı Motivasyonu Ölçeğine Ait Tanımlayıcı İstatistikler

\begin{tabular}{lccccc}
\hline \multicolumn{1}{c}{ Değişkenler } & Ortalama & SS & Çarpıklık & Basıklık & $\begin{array}{c}\text { Cronbach } \\
\text { Alfa }\end{array}$ \\
\hline 1. Antrenman ve Kondisyon & & & & & .02 \\
2. Teknik Beceri Öğretimi & 6.40 & 0.80 & -1.083 & 1.418 & .762 \\
3. Zihinsel Hazırlık & 5.97 & 1.23 & -1.374 & 1.308 & .877 \\
4. Hedef Belirleme & 5.85 & 1.18 & -1.013 & 0.478 & .912 \\
5. Yarışma Stratejileri & 6.27 & 0.98 & -1.527 & 1.482 & .912 \\
6. Olumlu Antrenör Davranışları & 6.35 & 0.88 & -1.604 & 1.989 & .858 \\
7. Olumsuz Antrenör Davranışları & 2.98 & 1.34 & 1.044 & 1.230 & .817 \\
8. Güç Gösterme Güdüsü & 3.94 & 0.56 & -0.262 & -0.743 & .696 \\
9. Başarıya Yaklaşma Güdüsü & 4.25 & 0.37 & -1.133 & 1.453 & .662 \\
10. Başarısızlıktan Kaçınma Güdüsü & 2.97 & 0.68 & -0.006 & -0.286 & .724 \\
\hline
\end{tabular}

Tablo 2. Antrenör Davranışları ve Başarı Motivasyonu Arasındaki İlişki

\begin{tabular}{lccccccccc}
\hline \multicolumn{1}{c}{ Değişkenler } & 1. & 2. & 3. & 4. & 5. & 6. & 7. & 8. & 9. \\
\hline 1. Antrenman ve Kondisyon & & & & & & & & & \\
2. Teknik Beceri Öğretimi & $.49^{* *}$ & & & & & & & & \\
3. Zihinsel Hazırlık & $.43^{* *}$ & $.57^{* *}$ & & & & & & & \\
4. Hedef Belirleme & $.53^{* *}$ & $.65^{* *}$ & $.66^{* *}$ & & & & & & \\
5. Yarışma Stratejileri & $.56^{* *}$ & $.69^{* *}$ & $.64^{* *}$ & $.77^{* *}$ & & & & & \\
6. Olumlu Antrenör Davranışları & $.57^{* *}$ & $.63^{* *}$ & $.51^{* *}$ & $.64^{* *}$ & $.73^{* *}$ & & & & \\
7. Olumsuz Antrenör Davranı̧ları & -.10 & $-.26^{* *}$ & -.13 & -.13 & $-.22^{* *}$ & $-.28^{* *}$ & & & \\
8. Güç Gösterme Güdüsü & .13 & $.33^{* *}$ & $.31^{* *}$ & $.20^{* *}$ & $.29^{* *}$ & $.18^{*}$ & -.10 & & \\
9. Başarıya Yaklaşma Güdüsü & $.21^{* *}$ & $.28^{* *}$ & $.19^{* *}$ & $.19^{* *}$ & $.27^{* *}$ & $.24^{* *}$ & -.06 & $.44^{* *}$ & \\
10. Başarısızlıktan Kaçınma Güdüsü & -.00 & $-.15^{*}$ & -.10 & -.06 & -.10 & -.07 & $.28^{* *}$ & $-.23^{* *}$ & .14 \\
\hline
\end{tabular}

$\mathrm{N}=192,{ }^{*} p<0.05,{ }^{* *} p<0.01$

Tablo 2, antrenör davranışları ve başarı motivasyonu arasındaki ilişkiye yönelik korelasyon analizi sonuçlarını göstermektedir. Güç gösterme güdüsü; teknik becerilerin öğretimi, zihinsel hazırlık, hedef belirleme, yarışma stratejileri ve olumlu antrenör davranışları ile pozitif ve anlamlı ilişkiye sahiptir. Başarıya yaklaşma güdüsü; antrenman ve kondisyon, teknik becerilerin öğretimi, zihinsel hazırlık, hedef belirleme, yarışma stratejileri ve olumlu antrenör davranıșları ile pozitif ve anlamlı ilișkiye sahiptir. Başarısızlıktan kaçınma güdüsü ise teknik beceri öğretimi ile negatif ve anlaml, olumsuz antrenör davranışları ile pozitif ve anlamlı ilişkiye sahiptir. Tablo 2'ye göre özetle, her iki ölçeğin de olumlu alt boyutları birbirleriyle pozitif, olumsuz alt boyutlarla da negatif ilişkiye sahiptir.

Tablo 3. Güç Gösterme Güdüsünün Yordanmasına İlişkin Standart Çoklu Regresyon Analizi

\begin{tabular}{lccccccc}
\hline \multicolumn{1}{c}{ Değişken } & $\mathrm{B}$ & $\begin{array}{c}\text { Standart } \\
\text { Hata }\end{array}$ & $\beta$ & $t$ & $p$ & İkili $r$ & Kismi $R$ \\
\hline 1. Antrenman ve Kondisyon & -0.03 & 0.04 & -0.05 & -0.67 & 0.49 & 0.13 & -0.05 \\
2. Teknik Beceri Öğretimi & 0.19 & 0.07 & 0.28 & 2.76 & $0.00^{*}$ & 0.33 & 0.20 \\
3. Zihinsel Hazırlık & 0.10 & 0.04 & 0.22 & 2.40 & $0.01^{*}$ & 0.31 & 0.17 \\
4. Hedef Belirleme & -0.09 & 0.05 & -0.20 & -1.75 & 0.08 & 0.20 & -0.12 \\
5. Yarışma Stratejileri & 0.13 & 0.07 & 0.24 & 1.86 & 0.06 & 0.29 & 0.13 \\
6. Olumlu Antrenör Davranışları & -0.08 & 0.06 & -0.13 & -1.21 & 0.22 & 0.18 & -0.08 \\
7. Olumsuz Antrenör Davranışları & -0.00 & 0.03 & -0.01 & -0.19 & 0.84 & -0.10 & -0.01 \\
\hline
\end{tabular}

$\mathrm{N}=192, R=0.407, R^{2}=0.166, F=5.214, \mathrm{p}<0.01$ 
Sporcular tarafindan algilanan antrenör davranışları ölçeğinin alt boyutlarına göre güç gösterme güdüsünün yordanmasına ilişkin regresyon analizi sonuçları Tablo 3 'te verilmiştir. Tablo 3 incelendiğinde sporcular tarafindan algılanan antrenör davranışları ölçeğinin alt boyutları ile sporcuların güç gösterme güdüsü yüksek düzeyde anlaml ilişki vermektedir, $R=0.407, \quad \mathrm{R}^{2}=0.166$, $p<0.01$. Sporcuların antrenör davranışlarını değerlendirme ölçeğinin alt boyutları birlikte, güç gösterme güdüsündeki varyansın yaklaşık \%17'sini açıklamaktadır. Regresyon katsayılarının anlamlılığına ilişkin t-testi sonuçları incelendiğinde ise, sadece teknik beceri öğretimi ve zihinsel hazırlık alt boyutlarının güç gösterme güdüsü üzerinde anlamlı bir yordayıcı olduğu görülmektedir.

Tablo 4. Başarıya Yaklaşma Güdüsünün Yordanmasına İlişkin Standart Çoklu Regresyon Analizi

\begin{tabular}{lccccccc}
\hline \multicolumn{1}{c}{ Değiş̧ken } & $\mathrm{B}$ & $\begin{array}{c}\text { Standart } \\
\text { Hata }\end{array}$ & $\beta$ & $t$ & $p$ & İkili $r$ & Kismi $R$ \\
\hline 1. Antrenman ve Kondisyon & 0.02 & 0.03 & 0.06 & 0.70 & 0.48 & 0.21 & 0.05 \\
2. Teknik Beceri Öğretimi & 0.08 & 0.04 & 0.17 & 1.68 & 0.09 & 0.28 & 0.12 \\
3. Zihinsel Hazırlık & 0.00 & 0.03 & 0.00 & 0.09 & 0.92 & 0.19 & 0.00 \\
4. Hedef Belirleme & -0.04 & 0.03 & -0.13 & -1.08 & 0.27 & 0.19 & -0.08 \\
5. Yarışma Stratejileri & 0.07 & 0.05 & 0.18 & 1.40 & 0.16 & 0.27 & 0.10 \\
6. Olumlu Antrenör Davranışları & 0.01 & 0.04 & 0.04 & 0.40 & 0.68 & 0.24 & 0.03 \\
7. Olumsuz Antrenör Davranışları & 0.00 & 0.02 & 0.02 & 0.37 & 0.71 & -0.06 & 0.02 \\
\hline
\end{tabular}

$\mathrm{N}=192, R=0.318, R^{2}=0.101, F=2.962, p<0.01$

Sporcular tarafindan algilanan antrenör davranışlarının başarıya yaklaşma güdüsünün yordanmasına ilişkin regresyon analizi sonuçları Tablo 4'te verilmiştir. Tablo 4'e göre, sporcular tarafindan algılanan antrenör davranıșları sporcuların başarıya yaklașma güdüsünü anlamlı olarak yordamaktadır $R=0.318, \quad R^{2}=0.101, \quad p<0.01$. Antrenör davranışları, başarıya yaklaşma güdüsündeki varyansın yaklașık \%10' unu açıklamaktadır. Regresyon katsayılarının anlamlılığına ilişkin t-testi sonuçları incelendiğinde ise antrenman ve kondisyon, teknik beceri öğretimi, zihinsel hazırlık, hedef belirleme, yarışma stratejileri, olumlu antrenör davranışları ve olumsuz antrenör davranışlarının bireysel etkilerinin anlamlı olmadığ 1 görülmektedir.

Tablo 5. Başarısızlıktan Kaçınma Güdüsünün Yordanmasına İlişkin Standart Çoklu Regresyon Analizi

\begin{tabular}{lccccccc}
\hline \multicolumn{1}{c}{ Değişken } & B & $\begin{array}{c}\text { Standart } \\
\text { Hata }\end{array}$ & $\beta$ & $t$ & $p$ & İkili $r$ & Kısmi $R$ \\
\hline 1. Antrenman ve Kondisyon & 0.04 & 0.06 & 0.06 & 0.76 & 0.44 & -0.00 & 0.05 \\
2. Teknik Beceri Öğretimi & -0.11 & 0.09 & -0.13 & -1.23 & 0.22 & -0.15 & -0.09 \\
3. Zihinsel Hazırlık & -0.04 & 0.05 & -0.07 & -0.77 & 0.43 & -0.10 & -0.05 \\
4. Hedef Belirleme & 0.02 & 0.07 & 0.04 & 0.32 & 0.74 & -0.06 & 0.02 \\
5. Yarışma Stratejileri & -0.02 & 0.09 & -0.03 & -0.25 & 0.80 & -0.10 & -0.01 \\
6. Olumlu Antrenör Davranışları & 0.06 & 0.08 & 0.08 & 0.74 & 0.45 & -0.07 & 0.05 \\
7. Olumsuz Antrenör Davranışları & 0.13 & 0.038 & 0.26 & 3.56 & $0.00^{*}$ & 0.28 & 0.25 \\
\hline N: 192, $R=0.311, R^{2}=0.097, F=2.823$, & $p<0.01$ & & & & & &
\end{tabular}

Sporcular tarafindan algılanan antrenör davranışları ölçeğinin alt boyutlarına göre başarısızlıktan kaçınma güdüsünün yordanmasına ilişkin regresyon analizi sonuçları Tablo 5'te verilmiştir. Tablo 5 
incelendiğinde sporcular tarafından algılanan antrenör davranışlarının sporcuların başarısızlıktan kaçınma güdüsünü anlamlı olarak yordadığ 1 görülmektedir $R=0.311$, $R^{2}=0.097, \quad p<0.01$. Antrenör davranışları, başarısızlıktan kaçınma güdüsündeki

\section{TARTIŞMA ve SONUÇ}

$\mathrm{Bu}$ araştırma antrenör davranışlarının adölesan futbolcuların spora özgü başarı motivasyonu ile ilişkisini ortaya koymak amacıyla yapılmıştır. Yapılan korelasyon analizi sonuçlarına göre, olumsuz antrenör davranışları arttıkça sporcuların başarısızlıktan kaçınma güdüsü de artmaktadır. Yapılan regresyon analizine göre ise olumsuz antrenör davranışlarının başarısızlıktan kaçınma güdüsüne anlamlı olarak katk1 sağladığı sonucuna varılmıştır. $\mathrm{Bu}$ bulgulara bakıldığında, olumsuz antrenör davranışlarının sporcuların başarısızlıktan kaçınma güdülerini artırabileceği söylenebilir. Yani olumsuz antrenör davranışını benimseyen antrenörlerle çalışan sporcular, daha az risk alma, kolay rakip arama ve güçlü rakiplerden kaçınma gibi davranışları sergilemeye eğilimli olabilirler. Alan yazında yapılan araştırmalar olumsuz antrenör davranışlarının sporcuların motivasyonu üzerinde olumsuz bir etkiye sahip olduğuna işaret etmektedir. Yapılan çalışmalar antrenörden algılanan olumsuz davranışların sporcuların ego yönelimlerini artırdığına işret etmektedir (Goldstein, 2016; Koh ve Wang, 2015). Yani olumsuz antrenör davranış1 gösteren antrenörlerle çalışan sporcular sadece sonuca odakl1 olabilirler. Performanslarını geçmiş performanslarıyla değil başkalarının performansıyla kıyaslayıp başarıya kolay yoldan ulaşmayı tercih edebilirler. Bir başka çalışmada ise antrenörlerin olumsuz davranışları ile sporcuların güdülenmemesi arasında olumlu yönde bir ilişki bulunmuş̧tur (Noor vd., 2019). Noor vd.,'nin (2019) araştırması, olumsuz antrenör davranıșının sporcuların motivasyonunu olumsuz olarak etkilediğini göstermektedir.

Sporcuların başarıya yaklaşma güdüsü ve güç gösterme güdüsü, olumlu antrenör davranışları, teknik beceri öğretimi, zihinsel varyansın yaklaşık \%10' unu açıklamaktadır. Regresyon katsayılarının anlamlılığına ilişkin t-testi sonuçları incelendiğinde ise sadece olumsuz antrenör davranışları alt boyutunun başarısızlıktan kaçınma güdüsünü anlamlı olarak açıkladığı belirlenmiştir.

Hazırlık, hedef belirleme ve yarışma stratejileri gibi antrenör davranışları ile pozitif ve anlamlı bir ilișkiye sahiptir. Bulguları incelediğimizde olumlu antrenör davranışını benimseyen antrenörlerle çalışan sporcuların başarı için çaba sarf etme ve başarıya ulaşmak için daha fazla mücadele ortaya koymaya eğilimli olabileceği söylenebilir. Özellikle takım sporları açısından bu durum kritik öneme sahiptir. Çünkü takım üyeleri kimi zaman başarı için eşit miktarda mücadele ortaya koyamayabilirler. Nitekim bu durum sosyal aylaklık olarak adlandırılmaktadır ve takım üyelerinin varlığında sporcunun daha az çaba gösterme davranışını tanımlamaktadır (Koruç, 2007). Olumlu antrenör davranışı ise bu durumu önleyen bir unsur olarak görünmektedir. Öte yandan, yine takım sporları özelinde, takımdaki her birey için müsabakanın sonucunda alınacak skor aynı derecede öneme sahip olmayabilir. Başarılı bir maç sonucu ise büyük ölçüde tüm üyelerin başarıya odaklanması ile mümkündür. $\mathrm{Bu}$ sebeple olumlu antrenör davranışı sporcuların başarıya ulaşma güdüsünü artırarak takımın başarıya ulaşmasına da katkı sağlayan bir unsur olarak görülebilir. Alan yazındaki araştırmalar, sporcu ve antrenör arası iletişimin artmasının, sporcunun güç gösterme ve başarıya ulaşma güdüsü ile olumlu yönde bir ilişkiye sahip olduğunu ortaya koymuştur (Abakay ve Kuru 2013; Abakay, 2010; Kılıçkaya vd., 2020). İlgili çalışmalar antrenör ve sporcu arasındaki olumlu iletişim ikliminin sporcunun başarı motivasyonu üzerindeki etkisine işaret etmektedir. Bu sebeple kulüp içi tüm paydaşların fikir ve düşüncelerini olumlu ve yapıcı bir dille ortaya koymaları onların daha rahat ve mutlu hissetmesine katk1 sağlayarak başarı motivasyonlarını artırabilir. Bu konuyla ilgili yapılan bir çalışma, bu noktaya dikkat çekerek, sporcuların mutlu hissetmesine katkı sağlayan ve onlara mutlu hissedecekleri bir ortam sunan antrenörlerin, sporcuların başarı motivasyonlarını artırdığına işaret etmektedir (Özgün vd., 2017). 
Sporcuların güç gösterme güdüsüne katkı sağlayan antrenör davranışlarının belirlenmesine yönelik gerçekleştirilen regresyon analizine göre; antrenör davranışlarından teknik beceri öğretimi ve zihinsel hazırlık, sporcuların güç göstermek güdüsüne anlamlı olarak katkı sağlamıștır. Bu bağlamda, sporcunun teknik kapasitesi yükseltmeye ve zihinsel becerilerini desteklemeye yönelik antrenör davranışlarının sporcuların güç gösterme güdüsünü artırabileceği söylenebilir. Bulgularımızla yakın bir şekilde, Koh ve Wang (2015) tarafından yapılan bir çalışmada antrenörün teknik beceri ve zihinsel hazırlık davranışları ile sporcuların görev yönelimi arasında pozitif ve anlamlı bir ilişki vardır. $\mathrm{Bu}$ sonuç, sporcuların algıladıkları antrenörün zihinsel hazırlık ve teknik becerileri davranışları ile sporcuların daha olumlu bir güdüsel yönelime sahip olması arasında olumlu bir ilișki olduğunu göstermektedir. Diğer yandan Noor vd. (2019) tarafından yapılan araştırmada ise zihinsel hazırlık ve teknik beceri öğretimi ile sporcuların içsel motivasyonları arasında pozitif ve anlamlı bir ilişki bulunmuştur. Yani antrenörün zihinsel hazırlık ve teknik beceri öğretimi davranışlarının, sporcuların içsel motivasyonları için daha olumlu olabileceği ifade edilebilir.

Sporcuların başarıya yaklaşma güdüsü ve güç gösterme güdüsünün antrenör davranışlarından olumlu antrenör davranışları, teknik beceri öğretimi, zihinsel hazırlık, hedef belirleme ve yarışma stratejileri ile pozitif ve anlamlı bir ilişkiye sahip olduğu belirlenmiştir. Antrenman ve kondisyon ise sadece başarıya yaklaşma güdüsü ile pozitif ve anlamlı bir ilişki göstermiştir. Başarısızlıktan kaçınma güdüsü ise teknik beceri öğretimi ile negatif; olumsuz antrenör davranışları ile pozitif yönde ilişkilidir. Regresyon analizi sonuçlarına göre, teknik beceri öğretimi ve zihinsel hazırlığın sporcuların güç gösterme güdüsüne pozitif olarak katkı sağladığı belirlenmiştir. Olumsuz antrenör davranışları ise başarısızlıktan kaçınma güdüsüne pozitif olarak katk1 sağlamaktadır. Sonuç olarak, antrenörlerin olumsuz davranışlarının sporcuların başarısızlıktan kaçınma güdüsünü artırılabileceği ifade edilebilir. Antrenörün teknik beceri öğretimi ve zihinsel hazırlık davranışlarının ise sporcuların güç gösterme güdüsüne katkı sağlayacağı söylenebilir.

$\mathrm{Bu}$ çalışmanın bazı sinırlılıkları bulunmaktadır. İlk olarak, çalışmanın bulguları futbolcu adölesan erkek sporcularla sinırlıdır. Ayrıca araştırma kesitsel bir araştırmadır ve bulgular ilişkisel analizlerden sadece korelasyon ve regresyon analizlerine dayanmaktadır. Son olarak, sporcuların güdülenmesi ve antrenör davranışları değişkenleri sporcuların algılarına dayanan ölçme araçları ile ölçülmüştür. İleride yapılacak araștırmalar için de bazı öneriler sunulabilir. Yapılacak boylamsal araştırmalar ile antrenör davranışları ve sporcuların başarı motivasyonları arasındaki ilişkinin zaman içerisindeki değişikliği incelenebilir. Ayrıca, antrenör davranışları ile başarı motivasyonu arasındaki ilişki deneysel çalışmalar aracılığıyla veya yapısal eşitlik modellemesi yöntemi ile analiz edilebilir. Ayrıca, sporcuların güdülenmesi ve antrenör davranışları değişkenleri gözlem formları veya görüşme yöntemi ile de ölçülebilir. Son olarak, antrenörün eğitim durumu onun davranışlarını etkileyebildiğinden, antrenör eğitim durumunun antrenör davranışları ile sporcunun motivasyonu arasındaki ilişkiye etkisi incelenebilir.

\section{Yazarların Makaleye Katkı Beyanı}

Makale tasarımı, literatür taraması, makale yazımı, dergi yazım kurallarına uygun şekilde düzenlenerek gönderilmesi İhsan Sar1, Erolcan Çelik, Muharrem Aydın ve Selçuk Köytepe tarafından yapılmıştır.

\section{Çıkar Çatışması}

Yazarların beyan edecek herhangi bir çıkar çatışması yoktur.

\section{Finansal Destek}

$\mathrm{Bu}$ çalışmanın yapılabilmesi için herhangi bir finansal destek alınmamıştır.

\section{Etik Kurul Onayı}

$\mathrm{Bu}$ çalışma Helsinki bildirgesi ile uyumludur. Sakarya Uygulamalı Bilimler Üniversitesi Rektörlüğü Etik Kurulu'ndan onaylıdır (21.05.2021-E.12090). 


\section{Hakem Değerlendirmesi}

Kör hakemlik süreci sonrası yayınlanmaya uygun bulunmuş ve kabul edilmiştir.

\section{KAYNAKÇA}

Abakay, U. (2010). Futbolcu- antrenör iletişiminin farklı statülerdeki futbolcuların başarı motivasyonuyla ilişkisi (Doktora tezi). Erişim adresi Avesis Ankara - TR.

Abakay, U., Kuru, E., (2013). The communication level of woman footballers with coach and success motivation relationship. Gaziantep Üniversitesi Sosyal Bilimler Dergisi, 12(1), 20-33.

Begel, D., Burton, B. W. (2017). Spor psikiyatristi teori ve uygulama. (Çev. R. Üney, R. Emre Tan). İstanbul: Edebi Şeyler. (Orijinal yayın tarihi, 2000).

Chelladurai, P., \& Carron, A. V. (1983). Athletic maturity and preferred leadership. Journal of Sport and Exercise Psychology, 5(4), 371-380.

Chia, J. S., Pyun, D. Y., \& Kwon, H. H. (2015). The impact of congruence between perceived and preferred leadership on satisfaction among college studentathletes in Singapore. Asia Pacific Journal of Education, 35(4), 498-513.

Coşkun, R., Altunışık, R., \& Yıldırım, E. (2017). Sosyal Bilimlerde Araştırma Yöntemleri SPSS Uygulamall, Sakarya Yayıncilık, Güncellenmiş 9. Baskı, Sakarya.

Côté, J., Yardley, J., Hay, J., Sedgwick, W., Baker, J. (1999). An exploratory examination of the Coaching Behaviour Scale for Sport. Avante, 5(3), 82-92.

Deelen, I., Ettema, D., \& Kamphuis, C. B. (2018). Sports participation in sport clubs, gyms or public spaces: How users of different sports settings differ in their motivations, goals, and sports frequency. PloS one, 13(10), e0205198.

Egli, T., Bland, H. W., Melton, B. F., \& Czech, D. R. (2011). Influence of age, sex, and race on college students' exercise motivation of physical activity. Journal of American college health, 59(5), 399-406.

George, D., \& Mallery, P. (2019). IBM SPSS statistics 26 step by step: A simple guide and reference. New York: Routledge.
Goldstein, J. D. (2016). Coaches, climates," field" goals, and efficacy: A" de-construction" of the mastery-approach to coaching and examination of relationships to psychosocial outcomes in a youth football player development program (Doktora tezi). Erişim adresi ProQuest Dissertations and Theses - USA \& Maryland.

Jensen, F. E., (2017). Ergen beyni. (Çev. C. E. Topaktaş). İstanbul: Hep Kitap. (Orijinal yayın tarihi, 2015).

Karadă̆, D. (2013). Yüzme antrenörlerinin bir liderlik özelliği olan iletişim becerilerinin yüzücülerin motivasyonları üzerindeki etkileri (Yayınlanmamış Yüksek Lisans Tezi). Marmara Üniversitesi, Sağllk Bilimleri Enstitüsü, İstanbul.

Karimi, M., Heydarinejad, S., \& Shafynia, P. (2012). The relationship between coaches' leadership behaviors and success motivation in women players of volleyball teams in Khuzestan Province. International Journal of Sport Studies, 2(3), 168-172.

Khaksari, G., Saboonchi, R., \& Soleymani, M. (2019). The role of emotional intelligence and leadership style of coaches in Success motivation and commitment of elite wrestlers in Iran. Contemporary Studies On Sport Management, 9(17), 69-79.

Kılıçkaya, O., Türk, N., Ertekin, A. B., \& Kaya, A. (2020). THE effect of communication skills of football coaches on the footballers'motivation for success. European Journal of Physical Education and Sport Science, 6(8), 116126.

Kim, B. J., Williams, L., \& Gill, D. L. (2003). A cross cultural study of achievement orientation and intrinsic motivation in young USA and Korean athletes. International Journal of Sport Psychology, 34(2), 168-184.

Koh, K. T., \& Wang, C. K. J. (2015). Gender and type of sport differences on perceived coaching behaviours, achievement goal orientations and life aspirations of youth Olympic games Singaporean athletes. International Journal of Sport and Exercise Psychology, 13(2), 91-103.

Koruç, Z., Kocaekşi, S., \& Esenyel, C. (2007). Futbol seyircisinin futbolcu üzerine 
etkileri. Gazi Beden Eğitimi ve Spor Bilimleri Dergisi, 12(1), 11-24.

Mansoori, S., \& Zardoshtiyan, S. (2016). the relationship between coach-athlete and achievement motivation elite athletes Kermanshah Province. Scientific Journal of Organizational Behavior Management in Sport Studies, 3(1), 69-76.

Mohd Noor, N., Hassan, M. F., Soh, K. G., \& Seruti, J. F. (2019). The relationship of coaching behavior towards the motivation of football athletes in Malaysia sports' school. Malaysian Journal of Sport Science and Recreation, 15(1), 57-67.

Özgün, A., Yaşartürk, F., Ayhan, B., \& Bozkuş, T. (2017). Hentbolcuların spora özgü başarı motivasyonu ve mutluluk düzeyleri arasındaki ilişkinin incelenmesi. Uluslararasl Kültürel ve Sosyal Araștırmalar Dergisi, 3(2), 83-94.

Sage, G.H. (1977). Introduction to motor behavior." A neuropsychological approach. London: Addison-Wesley Publishing Company.

Şahin, Ş., \& Özçelik, Ç. Ç. (2016). Ergenlik dönemi ve sosyalleşme. Cumhuriyet Hemşirelik Dergisi, 5(1), 42-49.

Tiryaki, Ş., Gödelek, E. (1997). Spora Özgü Başarı Motivasyonu Ölçeğinin Türk Sporcuları için Uyarlanması Çalıșması, I. Uluslararast Spor Psikolojisi Sempozyumu Bildiri Kitapçığı. Bağırgan Yayınevi, 128-141.

Toros, T. (2011). Genç erkek basketbolcularda, turnuva öncesi ve turnuva sonras sporcuların algıladıkları antrenörlük davranışı, hedef yönelimleri, takım sargınlığı, algılanan motivasyonel iklim ve kolektif yeterlik arasındaki farklılığın analizi. Pamukkale Journal of Sport Sciences, 2(1), 39.

Weinberg, R. S. and Gould, D. (2015). Spor ve Egzersiz Psikolojisinin Temelleri, (Çev. M. Şahin ve Z. Koruç) Ankara: Nobel Yayıncilık.

Willis, J. D. (1982). Three scales to measure competition-related motives in sport. Journal of Sport and Exercise Psychology, 4(4), 338-353.

Yan JH, McCullagh P. Cultural influence on Youth's motivation of participation in physical activity. Journal of Sport Behavior. 2004;27(4) 378-90.

Yapar, A., \& İnce, M. I. (2014). Sporcular için antrenör davranışlarını değerlendirme ölçeğinin Türkçe uyarlaması (SADDÖ): geçerlik ve güvenirlik çalışması. Spor Bilimleri Dergisi, 25(4), 203-212. 